\title{
Osobnostně sociální rozvoj - o významu pojmu optikou pedagogického diskursu ${ }^{1}$
}

\section{Personal social development - on the meanings of this concept through the optics of pedagogical discourse}

\author{
Jan Kolář, Jan Nehyba, Bohumíra Lazarová
}

\begin{abstract}
Abstrakt: V příspěvku autoři pojednávají o možnostech nahlížení frekventovaného a nejednoznačně chápaného pojmu osobnostně sociální rozvoj. V odborné literatuře a pedagogické praxi dochází v rozdílných souvislostech k souběžnému užívání termínů, jakými jsou osobní, osobnostní, či osobnostně sociální rozvoj, vývoj, růst, apod. V textu jsou nabídnuty různé přístupy, resp. možnosti chápání a užívání zmíněného pojmu tak, jak se $\mathrm{s}$ nimi lze setkávat $\mathrm{v}$ teoretických pramenech i v bezprostřední pedagogické realitě. Tato pojetí autoři představují $\mathrm{v}$ šesti kategoriích zaměřených především na faktickou uchopitelnost jednotlivých koncepti̊ a jejich využitelnost $v$ teoretické i empirické rovině (tzn. jasnost a jednoznačnost vymezení cílů, metod, prostředků a indikátorů výstupů).
\end{abstract}

Klíčová slova: osobnostně sociální rozvoj, osobnost, výchova, příprava na profesi, kvalita života

\begin{abstract}
The authors of this paper deal with the possibilities of understanding the frequently used and ambiguously perceived concept of Personal-Social Development. As we can see in literature and pedagogical praxis, the concepts of personal, social and personal-social development, evolution, growth or maturation are used side by side in very different circumstances. This paper offers various ways of understanding and using the concept of personal-social development in theoretical sources and pedagogical praxis. The authors introduce these approaches in six categories focused on the actual understanding of the concepts and their utilization in theoretical and empirical level (unambiguity in defining the goals, methods, means and outputs indicators).
\end{abstract}

Keywords: personal-social development, personality, education, preparation for profession, quality of life

\section{1 Úvodem}

Když jsme se vrámci aktivit Akademického centra osobnostního rozvoje při Ústavu pedagogických věd Filozofické fakulty Masarykovy univerzity ${ }^{2}$ začali zabývat tématem osobnostně sociálního rozvoje (dále OSR), byli jsme si vědomi existence řady pojetí a př́stupů, s nimiž se lze v této oblasti výchovně vzdělávací reality střetnout, a měli jsme

\footnotetext{
${ }^{1}$ Text př́spěvku vznikl v souvislosti s realizací projektu Zkušenostní a reflektivni učení - podpora profesní prípravy studentů (reg. číslo CZ.1.07/2.2.00/15.0202) financovaného Evropskou unií a státním rozpočtem České republiky.

${ }^{2} \mathrm{http}: / / \mathrm{www} \cdot$ acor.cz
} 
$\mathrm{v}$ úmyslu tyto koncepce prozkoumat a inspirovat se jimi při tvorbě a vývoji vlastního vzdělávacího modelu.

Pojmy $\mathrm{OSR}^{3}$ (a často ve stejných souvislostech používané ekvivalenty jako růst, kultivace, zrání apod.) jsou využívány v pramenech různého charakteru a zaměření a nelze si rovněž nepovšimnout frekventovaného a zároveň živelného uživání těchto pojmů laickou veřejností.

Stejných pojmů se tak používá při realizaci natolik rozdílných činností a aktivit, jako jsou např. sociálně adaptační kurzy pro žáky základních a středních škol, programy profesního rozvoje pracovníků, psychoterapeutická sezení, nebo také kurzy pro matky na rodičovské dovolené či volnočasové aktivity určené seniorům. V neposlední řadě s pojmem OSR operují také představitelé tzv. nových náboženských hnutí slibujících svým „obětem“ lepší a št’astnější život.

Nalézt jasnější definici, která by byla vyjádřením konsensu nad chápáním tohoto pojmu, či alespoň jeho rámcové vymezení a ukotvení je však, zdá se, nemožné. Pojem OSR tak působí poněkud nejasně a zároveň všeobsažně. To nás přivedlo k úvahám nad možnými významy tohoto pojmu. Zajímaly nás rozdíly a synergie $\mathrm{v}$ jednotlivých pojetích, empirická uchopitelnost a možné využití v bezprostřední pedagogické realitě. V následujících řádcích bez nároku na úplnost a definitivní platnost nastíníme některé souvislosti spojené s užíváním termínu OSR a v šesti oddělených kategoriích nabídneme výsledky analýzy zaměřené na využívání zmíněného konceptu $\mathrm{v}$ různých kontextech optikou vybraných pedagogických kategorií, jako jsou vzdělávací cíl, obsah či metoda.

\section{Osobnostně sociální rozvoj jako cesta $\mathbf{k}$ naplnění ideálu}

Řada autorů hovoří o OSR ve vztahu k dosažení vzdáleného a neurčitého ideálu. V této souvislosti je OSR často spojován s pojmem výchova a je s ním operováno ve snaze definovat její cíle. Připomeňme např. některé z definic výchovy jako snahy o záměrné a cílevědomé ovlivnění OSR vychovávaných (Pelikán, 2009; Průcha, 2009) či jako podpory integrované a socializované osobnosti schopné vlastního bytí se sebou samým, s druhými lidmi i se širším okolním světem (Pelikán, 2007; Průcha, Walterová, Mareš, 2009). Dalším z příkladů tohoto pojetí může být Jiráskovo (2004) chápání OSR ve vztahu k naplnění starořeckého ideálu kalokagathie tedy jako „, všestranného rozvoje k harmonii směrujicí osobnosti“ (s. 15).

Idealistickému pohledu dominuje velmi obecný cíl, k jehož dosažení má veškeré snažení směřovat. Dílčí (operativní) cíle, strategie, koncepce, metody, popřr. postupy, jak jej dosáhnout, však obvykle rozpracovány nejsou, což v konečném důsledku může znamenat, že potenciál pro OSR lze úspěšně spatřrovat v kdejaké lidské činnosti. Př́nosem tohoto pojetí tak zůstává především důraz kladený na význam stanovení centrální vize, kterou je v OSR zapotřebí sledovat. Za výrazné riziko lze naopak považovat jeho obtížnou (ne-li nemožnou) uchopitelnost v empirické i aplikační rovině, nebot' jak konstatuje Brezinka (1996), mají-li

\footnotetext{
${ }^{3} \mathrm{~V}$ literatuře bývají pojmy osobnostní a sociální, osobnostně sociální a osobnostní rozvoj zpravidla užívány jako synonyma. V textu se tak pojem může objevit ve všech těchto podobách. Upřednostňována bude však varianta pojmu osobnostně sociální tak, aby byla zdůrazněna jeho sociální složka a zároveň i vzájemná provázanost a podmíněnost obou komponent. Další pojmová neujasněnost se týká nediferencovaného používání spojení osobní a osobnostní rozvoj (v zahraniční literatuře personal a personality development - viz např. Mroczek \& Little, 2006; L'Abate, \& Bryson, 1993; Johns, 2005; McLaughlin \& Byers, 2001). V prŕpadě přenosu zahraničních modelů do tuzemského prostředí pak dochází k paradoxním situacím, jako v případě Valentovy (2006) osobnostní a sociální výchovy vycházející z britské koncepce personal and social education.
} 
být edukační ideály využity jako pedagogická pomůcka, musí být nejprve jasně řečeno, co znamenají a jak je použít.

\section{Osobnostně sociální rozvoj jako hybatel společenských proměn}

Podobnou rétoriku používají rovněž často dokumenty politického rázu - nejčastěji v podobě strategických a koncepčních materiálů. Význam OSR je zde spojován s dosahováním celospolečenského užitku, jako např. plné zaměstnanosti, optimální konkurenceschopnosti, udržitelného růstu, aktivního občanství apod. (viz např. Memorandum, 2001; Národní, 2001), nebo se o něm hovoří např. jako o nástroji možných sociálních reforem (Prod'homme, 2002). Míra obecnosti použitých formulací a zdůvodnění se zde pohybuje na ještě vyšší úrovni, $\mathrm{s}$ čímž zároveň logicky klesá i jejich př́ípadná využitelnost pro seriózní koncepci OSR. Na druhou stranu tyto dokumenty díky svému významu pro oblast vzdělávací politiky umožňují legitimizovat existenci řady programů OSR, jejichž realizace nebyla v minulosti vnímána jako samozřejmá.

\section{Osobnostně sociální rozvoj jako proces duševního vývoje člověka}

$\mathrm{V}$ jiných souvislostech je OSR nahlížen $\mathrm{v}$ textech autorů zabývajících se především vývojovou či biodromální psychologií a psychologií osobnosti. Osobnostní rozvoj ve smyslu progresivního psychosociálního vývoje člověka je zde chápán jako permanentní a vzájemně podmíněná interakce procesů zrání a učení (Balcar, 1991; Říčan, 2004; Turner \& Helms, 1995). OSR je tak v tomto pojetí do určité míry předem naprogramovaným dějem (zráním), který by nejprve měl v definovaném sledu událostí proběhnout tak, aby se otevřel prostor pro další psychosociální kultivaci (učení). Výhodou těchto konceptů bývá povětšinou pevné zakotvení v některé z teorií osobnosti, což nám umožňuje získat ucelený pohled na strukturu psychosociálního vývoje člověka. Př́nos těchto pojetí lze proto spatřovat zejména ve formulaci konkrétních úkolů OSR $\mathrm{v}$ dílčích etapách životního cyklu. Silný důraz na teoretickou reflexi problematiky však zastiňuje její aplikační rovinu. Téměř nerozpracovaná tak zůstává oblast obsahů a metod, prostřednictvím nichž by bylo možné stanovených úkolů OSR dosáhnout.

\section{Osobnostně sociální rozvoj jako forma aktivního života}

Do této kategorie pohledů na OSR lze zařadit pestrou paletu př́istupů a činností, jejichž společným jmenovatelem je orientace na životní aktivitu. Důvodem pro ni bývá představa o zásadách zdravého životního stylu, smysluplném trávení volného času, kvalitě života apod., která člověka motivuje k práci na sobě samém. Často jde o účast na programech neformálního zájmového vzdělávání, ale stejně tak jde i o aktivity neorganizovaného a neinstitucionálního informálního učení (Knotová, 2006). Za aktivity s potenciálem OSR se zde proto směle považují snad všechny činnosti, o nichž jsou jejich propagátoři či „,konzumenti“ přesvědčeni, že lidem prospívají. Od dětských táborů a sportovních či umělecky zaměřených kroužků, přes kurzy jógy, adrenalinové atrakce a turistické poznávací zájezdy, až po nabídky univerzit třetího věku, wellness center, četbu knih či rybaření (srov. např. Hodaň, Dohnal, 2005). Přestože propagátoři, organizátoři i realizátoři těchto činností zpravidla deklarují jejich napojení na nějakou centrální vizi, zřetelně zde dominuje důraz na „výchovně vzdělávací obsah, jehož provázání s cíli lze často považovat za volné, zamlžené, či výslovně sporné. Nejinak je tomu v případě zvolených metod a teoretické opory vůbec. Tento všeobjímající 
způsob chápání OSR proto, domníváme se, představuje neuchopitelné a svým způsobem i neovlivnitelné břemeno.

\section{Osobnostně sociální rozvoj jako příprava na (kvalitní) život}

Autoři následujících koncepcí vycházejí z předpokladu, že optimální fungování v každodenním světě není pro člověka nic samozřejmého. Soubor tzv. „životních dovedností“ (Valenta, 2006), přestože jsou pro lidský život zásadní, totiž ne vždy a ne všichni získáváme v procesu socializace či edukace na dostatečné úrovni.

Jednou z možností, jak lidem tyto dovednosti zprostředkovat, je zakomponovat př́pravu na všední život jako téma a úkol již do školní výchovy a vzdělávání (McLaughlin \& Byers, 2001; Otten, 1999). Ukázkou implementace kurikula životních dovedností (Valenta, 2006) je $\mathrm{v}$ našich podmínkách např̀. jeho zařazení $\mathrm{v}$ podobě průřezového tématu do rámcových vzdělávacích programů. Odraz tohoto pojetí OSR lze spatřovat i v programech primární prevence sociálně patologických jevů, založených na systematickém posilování osobnostních a sociálních dovedností jako nástrojích umožňujících odolávat tlaku rizikového sociálního prostředí, či snad jako téma různorodých sebezkušenostních, podpůrných či dokonce psychoterapeutických skupin organizovaných jak veřejnými institucemi vzdělávacího či zdravotnického zaměření, tak i neziskovým sektorem (nap̌r. Hughes \& Youngson, 2009).

Z pohledu těchto koncepcí je OSR kompaktním edukačním systémem, který směřuje $\mathrm{k}$ naplnění vize. Tato vize je však rovněž operacionalizována do struktury konkrétních edukačních cílů $\mathrm{s}$ jasně stanovenými indikátory umožňujícími měřit míru jejich dosažení (např. Srb, 2007). Další předností je dostatečné teoretické ukotvení v některé z teorií osobnosti (např. Drapela, 1998; Engler, 2008) nebo vzdělávací teorii (napřr. Bertrand, 1998) a stejně tak i opora ve validní metodě a relevantním edukačním obsahu.

\section{Osobnostně sociální rozvoj jako podpora profesní kultivace}

Autorsky nejvděčnější pojetí nahlíží na OSR optikou přípravy na budoucí či stávající profesi. Vhodný profil pracovníka totiž hraje významnou úlohu snad v každém lidském povolání, a tak se téma OSR nezřídka usazuje do kurikul profesní př́pravy ${ }^{4}$. Zdaleka již nejde jen o prrípravu pro pomáhající profese, stále běžnější je i specializovaná osobnostní př́íprava napřs. manažerských a vedoucích pracovníků (Smékal, 2008) a v pozadí nestojí ani řada jiných humanitních, prírodních a dokonce i technických oborü ${ }^{5}$. OSR se tak stává úkolem vzdělavatelů $\mathrm{v}$ institucích počátečního i dalšího vzdělávání. Stále většího významu v tomto ohledu nabývá i profesní podpora neinstitucionálního charakteru, jako jsou např. supervize, mentoring, koučing apod. (Kinkor \& Baštecká, 2009; Lazarová, 2006).

Různorodou škálu př́stupů, koncepcí a konkrétních programů, které se v této kategorii objevují, spojuje společná orientace na rozvoj a možnosti využití vlastního potenciálu studentů/pracovníků pro práci s lidmi. Hlavním cílem je tak získání specifických profesních dovedností umožňujících co možná nejúčinnější a nejefektivnější pracovní výkon. V rámci tohoto pojetí se tak děje jednak prostřednictvím aktivit krátkodobého charakteru (semináře,

\footnotetext{
${ }^{4}$ Jak upozorňuje např. Lazarová (2006), v této souvislosti dochází k přirozenému prolínání pojmů osobnostní a profesionální rozvoj.

5 Kde je však téma osobnostně sociálního rozvoje až povážlivě často redukováno „pouze“ na nácvik vybraných měkkých dovedností (srov. např. Mühleisen \& Oberhuber, 2008).
} 
kurzy), o jejichž finálním dopadu lze však mít (vzhledem k časté absenci napojení na komplexní a strukturovaný program) jistou pochybnost. Druhý pohled reprezentuje naopak programy OSR tvořící ucelený vzdělávací systém, který vychází ze svébytné koncepce či teorie s jasně definovanou strukturou a vzájemně provázaným obsahem, vhodným metodickým arsenálem a především pak jednoznačně stanoveným a operacionalizovaným vzdělávacím cílem. Stav existence takových programů u nás mapoval v minulosti např. Svatoš (2003), který jen v podmínkách počátečního vzdělávání učitelů identifikoval pět př́kladů funkční koncepce OSR. O slovo se však v posledních letech stále hlasitěji hlásí i další přístupy (např. Lazarová \& Koláŕ, 2007; Psychosomatické, 2008 apod.). Za prŕíklad z oblasti dalšího profesního vzdělávání lze zase považovat modely príípravy budoucích psychoterapeuti̊ ve formě sebezkušenostních výcvikư ${ }^{6}$, jejichž podstatná část je zpravidla věnována osobnostně sociální př́ípravě profesionála (např. Yalom \& Lescz, 2007).

\section{Závěr}

Rozsah užívání pojmu OSR je, zdá se, v současnosti velmi široký a pestrý a ne vždy slučitelné jsou kontexty, v nichž bývá aplikován. Jsme nicméně přesvědčeni, že i přes nastíněnou problematičnost tento pojem přináší užitek. Předně do značné míry umožňuje dostat pod jednu střechu oblast, která se v minulosti rozvíjela a i dnes se dále rozvíjí nad rámec jedné disciplíny, jednoho př́stupu a pohledu na svět. Tímto společným zastřešením nikdo a nic neztrácí ze své autonomie a svébytnosti. Naopak, jednotlivé diskursy mohou vedle sebe koexistovat a nadále podporovat svůj vlastní vývoj. Zároveň je zde však zdůrazněn společný zájem a směřování, tedy to, co od multidisciplinárního pojetí a mezioborové spolupráce očekáváme. Našemu pojetí jsou bližší koncepce vycházející z globálních cílů a stanovených vizí, mající stabilní oporu v relevantní vzdělávací teorii či teorii osobnosti (především poslední dva přístupy), které současně umožňují nahlédnout i výchovně vzdělávací obsah s rozpracovanou strukturou dílčích cílů navázaných na pestrou zásobárnu vhodných metod a postupů. Síla těchto přístupů netkví přitom jen v jejich větší komplexnosti, ale především ve vzájemné a promyšlené provázanosti všech dílčích součástí tvořících svým propojením jednolitý harmonický celek. Optikou pedagogického diskursu proto na OSR nahlížíme jako na komplexní výchovně vzdělávací systém prŕípravy na kvalitní osobní či profesní život realizovaný profesionálními lektory, kteří mají k dispozici legitimní a relevantní teoretickou i metodickou oporu.

\section{Literatura}

Balcar, K. (1991). Úvod do studia psychologie osobnosti. Chrudim: Mach.

Bertrand, Y. (1998). Soudobé teorie vzdélávání. Praha: Portál.

Brezinka, W. (1996). Filozofické základy výchovy. Praha: Zvon.

Drapela, J. V. (1998). Přehled teorii osobnosti. Praha: Portál.

Engler, B. (2008). Personality Theories. Boston: Wadsworth Publishing.

Hodaň, B, \& Dohnal, T. (2005). Rekreologie. Olomouc: Hanex.

Hughes, J., \& Youngson, S. (2009). Personal development and clinical psychology. Chichester: Blackwell Publishing.

Jirásek, I. (2004). Vymezení pojmu zážitková pedagogika. Gymnasion, (1), 6-16.

Johns, H. (2005). Personal development in counsellor training. London: Sage.

\footnotetext{
${ }^{6}$ Zmiňme např. v poměrech ČR tradiční a zřejmě nejrozšiřrenější psychoterapeutické výcviky typu SUR.
} 
Kinkor, M., \& Baštecká, B. (2009). Supervize v pomáhajících profesích. In B. Baštecká (Ed.), Psychologická encyklopedie: Aplikovaná psychologie (pp. 388-394). Praha: Portál.

Knotová, D. (2006). Neformální zájmové vzdělávání dospělých ve volném čase. In Sborník praci Filozofické fakulty brněnské univerzity, řada pedagogická, U 11 (pp. 67-79). Brno: MU v Brně.

L'abate, L., \& Bryson, Ch. H. (1993). A theory of personality development. Hoboken: Wiley.

Lazarová, B (1996). Cesty dalšiho vzdělávání učitelů. Brno: Paido.

Lazarová, B., Kolář, J. (2007). Osobnostní př́prava studentů pedagogických oborů. In D. Knotová, L. Hloušková, \& K. Zavadilová (Eds.), Trendy v připravě pedagogických pracovníků (pp. 170-177). Brno: Konvoj.

McLaughlin, C., \& Byers, R. (2001). Personal and social development for all. London: David Fulton Publishers.

Memorandum o celoživotním učení. Pracovni materiál Evropské komise, listopad 2000 (2001). Praha: MŠMT.

Mroczek, D. K., \& Little, T. D. (Eds.). (2006). Handbook of personality development. Mahwah: Lawrence Erlbaum Associates.

Mühleisen, S., \& Oberhuber, N. (2008). Komunikační a jiné měkké dovednosti. Soft skills v praxi. Praha: Grada.

Národni program rozvoje vzděláváni v České republice. Bílá kniha. (2001). Praha: Ústav pro informace ve vzdělávání.

Otten, L. (1999). A curriculum for personal and social education. London: David Fulton Publishers.

Pelikán, J. (2007). Hledáni těžiště výchovy. Praha: Karolinum.

Pelikán, J. (2009). Fenomén výchova. In J. Průcha (Ed.), Pedagogická encyklopedie (pp. 19-23). Praha: Portál.

Prod'homme, G. (2002). Le Développement personnel, c'est quoi? Savoir enfin de quoi on parle. Paris: Dunod.

Průcha, J. (2009). Přehled pedagogiky. Úvod do studia oboru. Praha: Portál.

Průcha, J., Walterová, E., \& Mareš, J. (2009). Pedagogický slovník. Praha: Portál.

Psychosomatické disciplíny v prípravě pedagogů: východiska a první zkušenosti. (2008). Brno: Paido.

Říčan, P. (2004). Cesta životem. Praha: Portál.

Smékal, V. (2008). Selfmanagement jako cesta k sobě a druhým. In J. Kolář, B. \& Lazarová (Eds.), K sobé, $k$ druhým, $k$ profesi: Teorie, programy a metody osobnostního a sociálního rozvoje pedagogických pracovniku (pp. 8-25). Brno: MU.

Srb, V. a kol. (2007). Jak na osobnostní a sociální výchovu? Praha: Projekt Odyssea.

Svatoš, T. (2003). Koncept dovednostní př́ípravy učitelů v České republice. Pedagogická revue, 55(5). (pp. 441-456).

Turner, J. S., \& Helms, D. B. (1995). Lifespan development. Fort Worth: Harcourt Brace College Publishers.

Valenta, J. (2006). Osobnostní a sociální výchova a její cesty k žákovi. Kladno: AISIS.

Yalom, I. D., \& Lescz, M. (2007). Teorie a praxe skupinové psychoterapie. Praha: Portál.

\section{Kontakt}

Mgr. Jan Koláŕr

Mgr. Jan Nehyba

Doc. PhDr. Bohumíra Lazarová, Ph.D.

Masarykova univerzita

Filozofická fakulta, Ústav pedagogických věd

A. Nováka 1, 60200 Brno

e-mail: jankolar@phil.muni.cz

nehyba@phil.muni.cz

lazarova@phil.muni.cz 


\section{Bibliografické údaje}

Kolář, J., Nehyba, J., \& Lazarová, B. (2011). Osobnostně sociální rozvoj - o významu pojmu optikou pedagogického diskursu. In T. Janík, P. Knecht, \& S. Šebestová (Eds.), Smiššený design v pedagogickém výzkumu: Sborník př́spěvků z 19. výročni konference České asociace pedagogického výzkumu (s. 349-355). Brno: Masarykova univerzita.

Dostupné z: http://www.ped.muni.cz/capv2011/sbornikprispevku/kolarnehybalazarova.pdf doi: 10.5817/PdF.P210-CAPV-2012-28 